\title{
LA GEOPOLÍTICA CAMBIANTE DEL CORONAVIRUS Y LA CAÍDA DEL NEOLIBERALISMO*
}

Mohammed Cherkaoui

* DOI: https://doi.org/10.18601/01245996.v23n44.06. Recepción: 02-042020, , aceptación: 27-11-2020. Sugerencia de citación: Cherkaoui, M. (2021). La geopolítica cambiante del coronavirus y la caída del neoliberalismo. $R e-$ vista de Economía Institucional, 23(44), 103-141.

a Profesor de Resolución de Conflictos, Universidad George Mason, Washington D.C. y ex miembro del Panel de Expertos de las Naciones Unidas. 


\section{La geopolítica cambiante del coronavirus y la caída del neoliberalismo}

Resumen Este artículo examina el contexto de propagación del nuevo coronavirus, la correlación con la inestabilidad de los mercados financieros mundiales y la caída de los precios del petróleo, y la preocupación por el futuro del capitalismo neorrealista. La primera parte aborda varias preguntas: ¿la pandemia fue provocada por la naturaleza o por el hombre?, ¿la investigación científica puede ayudar a separar la verdad de las tesis conspirativas? La segunda parte sugiere que el coronavirus impuso una economía de goteo de facto a la economía de goteo de Reagan, y muestra los trastornos económicos que ha provocado en países desarrollados y en desarrollo. Se concluye que un pequeño virus está obligando al sistema neoliberal dominante a revisar la realidad a la fuerza.

Palabras clave: Coronavirus, geopolítica; JEL: H50, D04

\section{The shifting geopolitics of coronavirus and the demise of Neoliberalism}

Abstact This paper examines the context of the spread of the new coronavirus, the correlation with the instability of world financial markets and the fall in oil prices, and concerns about the future of neorealist capitalism. The first part addresses several questions: was the pandemic caused by nature or by man? Can scientific research help to separate the truth from the conspiracy theses? The second part suggests that the coronavirus has imposed a de facto trickle-down economy on Reagan's trickledown economy, and shows the economic disruptions it has caused in developed and developing countries. It is concluded that a tiny virus is forcing the dominant neoliberal system to review reality by force.

Keywords: Coronavirus, geopolitics; JEL: H50, D04

\section{A mudança geopolítica do coronavírus e a queda do neoliberalismo}

Resumo Este artigo examina o contexto de disseminação do novo coronavírus, a correlação com a instabilidade dos mercados financeiros mundiais e a queda dos preços do petróleo, e as preocupações com o futuro do capitalismo neorrealista. A primeira parte aborda várias questões: A pandemia foi causada pela natureza ou pelo homem? A pesquisa científica pode ajudar a separar os verdade das teses da conspiração? A segunda parte sugere que o coronavírus impôs uma economia de gotejamento de fato à economia de gotejamento de Reagan e mostra as rupturas econômicas que causou nos países desenvolvidos e em desenvolvimento. Conclui-se que um pequeno vírus está forçando o sistema neoliberal dominante a rever a realidade pela força.

Palavras-chave Coronavírus, geopolítica; JEL H50, D04 
耳 $\mathrm{n}$ un gesto simbólico y muy irónico, el 12 de marzo de 2020 - Aaterrizó un avión chino en Roma, el epicentro europeo de propagación del coronavirus, con nueve expertos médicos y 31 toneladas de suministros médicos, unidades de cuidados intensivos, equipos de protección médica y medicamentos antivirales. Jack Ma, el empresario chino fundador del Grupo Alibaba, ofreció donar 500.000 kits de pruebas de coronavirus y un millón de máscaras a Estados Unidos, que declaró una emergencia nacional por el brote en la segunda semana de marzo. China ha sido el "taller del mundo", en las últimas tres décadas, proporcionando una cuarta parte de las manufacturas mundiales, como diría Paul Krugman. Curiosamente, China se ha posicionado como el médico y el laboratorio de Occidente. Desde hace más de dos meses, los esfuerzos por contener la pandemia en Europa y otros lugares indican la necesidad de cambiar el paradigma de manejo de la salud pública, la estrategia económica y la bioseguridad, así como de revisar el neorrealismo o capitalismo con esteroides.

A comienzos de febrero, el representante permanente de Italia ante la Unión Europea (UE), Maurizio Massari, pidió ayuda a través del Centro de Coordinación de Respuestas a Emergencias. "Pedimos suministros de equipo médico, y la Comisión Europea trasladó el 1lamamiento a los Estados miembros. Pero no funcionó" (Braw, 2020). E1 Centro sirve como centro de crisis de la UE, monitorea desastres naturales y provocados por el hombre, administra las necesidades de un Estado miembro que no puede manejar una crisis por sí solo, y transmite el llamamiento a otros Estados miembros, que pueden prestar ayuda voluntaria.

La negligencia europea ante la catástrofe de Italia ha hecho eco al resentimiento de los italianos, que se sintieron defraudados por otros Estados miembros en varias ocasiones; como hoy y en el pico de la crisis de refugiados de 2015, cuando cerca de 1,7 millones de personas llegaron al sur de Europa. La declaración de Massari refleja el tono amargo por la falta de solidaridad de Europa.

La crisis del coronavirus es similar a la crisis de los refugiados: la mayoría de los países que no son afectados de inmediato no están dispuestos a ayudar. Los diferentes países tienen diferentes percepciones de las amenazas. Nosotros [Italia] sentimos que el coronavirus es una amenaza global y europea que necesita una respuesta europea, pero otros países no lo ven así (ibíd.).

Una respuesta tan negativa de Bruselas, la capital de la UE, ha desconcertado a los observadores políticos y suscitado nuevas preguntas sobre el propósito de la UE, que una vez se percibió como la alianza 
post-estatal más unificada y estratégica del mundo. Elisabeth Braw, directora del proyecto Modern Deterrence en el Royal United Services Institute, dijo que los países de la UE "han fallado, en una vergonzosa abdicación de responsabilidad, para dar asistencia médica y suministros a Italia durante el brote. China ha llenado el vacío" (ibíd.).

Los historiadores económicos europeos recuerdan con temor la Peste Negra, que se extendió por el continente a mediados del siglo XIV y provocó la muerte de un tercio de la población. Este descenso demográfico provocó escasez de mano de obra, un aumento de los salarios y una reducción de la desigualdad, y cuestionó el sistema feudal europeo. También allanó el camino a la Revolución Industrial en la Gran Bretaña, que fue golpeada por el 'Rey cólera' en 1831-1832, 1848-1849, 1854 y 1867. La tuberculosis fue responsable de la muerte de un tercio de las víctimas en Gran Bretaña entre 1800 y 1850. E1 refrán de pesadilla vuelve hoy con más fuerza, pues las epidemias han sido "grandes igualadoras" y pueden tener efectos de largo plazo no solo para el crecimiento económico europeo, sino también para la economía mundial. Después de que la Reserva Federal de Estados Unidos decidió recortar la tasa de interés de referencia (por debajo de un rango de 1 a 1,25\%) y comprar 700 mil millones de dólares en bonos del Tesoro y valores respaldados por hipotecas en una reunión de emergencia del domingo 15 de marzo, el promedio del Dow Jones industrial se desplomó 2.250 puntos en la apertura del día siguiente y la negociación se suspendió casi de inmediato.

La propagación de la pandemia de COVID-19 casi ha paralizado al mundo. Cerró los vuelos internacionales y amenaza la existencia de muchas aerolíneas. Por ejemplo, la prohibición por 30 días de la mayoría de los vuelos de Europa a Estados Unidos, declarada por Donald Trump, que entró en vigencia el 14 de marzo, borrará las lucrativas rutas transatlánticas que reportaron ventas por 20 mil millones de dólares el año pasado. El drama real ha pasado de la representación de pueblos fantasmas en las películas de Hollywood a países fantasmas reales como Italia, España y Alemania. Otros países han optado por la cuarentena forzada de su población. Estamos en una era de discriminación viral autoimpuesta, entre uno y los demás, en entornos sociales, sitios de trabajo y reuniones públicas que alguna vez fueron acogedores, e incluso en iglesias, mezquitas y templos.

El presidente Trump enmarcó la pandemia en términos xenófobos y afirmó de modo sumamente irresponsable que "desaparecerá. Mantengan la calma. Se irá”. La nueva pandemia revela los aspectos más cínicos del neoliberalismo. En un debate sobre 'Capitalismo versus 
coronavirus', el tema central fue si debido al modelo neoliberal de capitalismo estadounidense ese país y su economía son especialmente inadecuados y mal equipados para afrontar una crisis de salud como la del coronavirus. Jeffery Sachs, director del Centro para el Desarrollo Sostenible de la Universidad de Columbia, afirmó:

No tenemos un sistema de salud pública. Tenemos un sistema privado con ánimo de lucro. Tenemos decenas de millones de personas sin cobertura médica. No tenemos pruebas sistemáticas. Estamos luchando; el virus se ha multiplicado durante semanas, y la pandemia se extiende en Estados Unidos (Hasan, 2020).

El año 2020 entrará en los libros de historia como un año que no solo expuso una falla de salud pública, sino que también marcó una era de recesión geopolítica y un momento de caída en desgracia del sistema neoliberal. El riesgo imprevisto para la salud pública hoy no se puede reducir "a virtudes éticas ni a la necesidad de inversiones"; y "la crisis pone de manifiesto las fallas de nuestra época miope, explotadora e hiperindividualista" (Pettersson, 2020).

Este escrito examina lo que llamo complejidad 3-C: a) el contexto de la propagación de la pandemia en 2020; b) la correlación con la inestabilidad de los mercados financieros mundiales y la caída repentina de los precios del petróleo a mediados de marzo, cuando el crudo Brent cayó un 12,2\%, 4,15 dólares, para negociarse a 29,68 dólares, su nivel más bajo desde enero de 2016; y c) la preocupación por el futuro del capitalismo neorrealista. La primera parte explora algunas dualidades que circulan en la esfera pública de todo el mundo: ¿es la COVID-19 una pandemia provocada "por la naturaleza" o "por el hombre”? ¿De qué modo la investigación científica puede ayudar a separar la verdad de las tesis conspirativas sobre una causa "deliberada" y una posible "manipulación" del virus en política internacional?

La segunda parte sugiere que el coronavirus ha impuesto una economía de goteo de facto a la economía de goteo de Reagan, que ha provocado graves trastornos económicos. En Nueva York, el centro turístico del mundo, el alcalde Bill de Blasio ordenó que los bares y restaurantes cerraran sus puertas en un esfuerzo por detener la propagación. E1 16 de marzo dijo a los neoyorquinos: "Debemos responder con una mentalidad de guerra”. En París, el presidente francés, Emmanuel Macron, en un sombrío discurso dijo a sus conciudadanos: "Estamos en guerra. No nos enfrentamos a otro ejército u otra nación. Pero el enemigo está allí: invisible, esquivo, y hace progresos”. Decidió reclutar al ejército para ayudar a trasladar los enfermos a los hospitales. 
En países en desarrollo como Marruecos y Filipinas, donde la agricultura, el turismo y las remesas de sus trabajadores en el extranjero son la columna vertebral de la economía nacional, los indicadores anuncian un resto del año sombrío porque los graves efectos de la pandemia empezarán en junio o julio. La agencia de las Naciones Unidas para el Comercio y el Desarrollo (Unctad) prevé que la incertidumbre y la inmovilidad económicas actuales pueden costar un billón de dólares en 2020 a la economía mundial.

$\mathrm{E} 1$ artículo concluye que un pequeño virus está obligando al sistema neoliberal dominante a revisar la realidad a la fuerza. Aboga por una dimensión humana y por la precedencia de la sociedad frente a la economía y el lucro en la reconstrucción de un sistema social democrático revisado, como debida corrección del neoliberalismo.

Como causa de una pandemia incontrolable, el coronavirus es un nuevo y desgarrador recordatorio de la fragilidad de la vida humana; y se puede interpretar como la súper enfermedad más democrática de nuestro tiempo, que no discrimina por raza, geografía, ideología política, riqueza ni grado de desarrollo o subdesarrollo. Como dijo un comentarista británico, "No perdona el Salir ni el Permanecer, ni al imán ni al médico chino, y no respeta fronteras nacionales. De modo que incluso cuando los líderes nacionales recurren a respuestas nacionales atávicas, los dictados de la ciencia y la razón han de salir a la superficie; no hay otro camino a seguir" (Hutton, 2020).

La extensión del contagio a los cinco continentes parece hacer eco a la moral de un artículo "El microbio como nivelador social", escrito por Cyrus Edson, comisionado de salud de la ciudad de Nueva York en 1895. A Edson lo maravillaron las reflexiones del comunista inglés del siglo XVII Gerrard Winstanley, quien dijo: "el microbio de la enfermedad no respeta a las personas”. Explicó que si bien la gente pobre corre mayor riesgo de contraer la enfermedad, los ricos nunca estarán totalmente a salvo de la infección. Para Edson, el "socialismo del microbio [...] es la cadena de enfermedad que une a todas las personas de una comunidad" (New Frame, 2020).

Durante marzo en particular, las naciones ricas de Europa, Norteamérica y el Golfo no pudieron evitar nuevos casos de infección mientras que los países pobres luchaban por proporcionar recursos básicos, agua, desinfectantes y medicamentos a sus ciudadanos. Entre enero y marzo, el coronavirus se propagó a velocidades inimaginables. 


\section{CIFRAS CRECIENTES}

E1 18 de marzo, la Organización Mundial de la Salud (OMS) anunció 200.106 casos confirmados, 8.010 muertes y 82.813 recuperados en 167 países. El alcance de la propagación muestra algunas áreas de concentración irónicas. La lista de países con más de 200 casos confirmados incluye: China 81.048, Italia 21,157, Irán 12,729, Corea del Sur 8.086, España 5,753, Francia 4.469, Alemania 3.795, Estados Unidos 1.678, Suiza 1.359, Reino Unido 1,144, Holanda 959, Suecia 924, Noruega 907, Dinamarca 827, Japón 780, Bélgica 689, Austria 655, Qatar 337, Grecia 227, Singapur 212 y Bahrein 211 (WHO, 2020). En China, casi 60 millones de personas ya estaban sujetas a cuarentena; e Italia se convirtió en epicentro europeo de la pandemia con un total de 21.157 casos y 1.441 muertes.

La OMS fue reacia a anunciar que el coronavirus era "oficialmente una pandemia" y solo decidió dar la mala noticia el 11 de marzo. La OMS define una pandemia como "la propagación mundial de una nueva enfermedad" (una epidemia se limita a "una comunidad o región”). Su Director General, Tedros A. Ghebreyesus, declaró: “Se presta mucha atención a esa palabra. Otras palabras importan más: prevención, preparación, liderazgo político y personas. Estamos juntos en esto" (World Economic Forum, 2020). Como señala Laura Spinney, autora de El jinete pálido - 1918: la epidemia que cambio el mundo, "Después de que el brote de gripe de 1918 mató a 50 millones, las naciones crearon nuevas organizaciones para luchar contra la infección. Pero en una época de pandemias y renovada rivalidad entre las grandes potencias, ya no son suficientes" (Spinney, 2020).

En Estados Unidos las infecciones por coronavirus pasaron de 1 caso el 22 de enero a 2.179 el 13 de marzo. En forma de "curva exponencial”, pues el número de casos se duplica cada dos o tres días, que en mayo serían cien millones de casos, según estima el Washington Post. Anthea Roberts y Nicolas Lamp, autores del próximo libro $G a-$ nadores y perdedores: narrativas sobre la globalización económica, señalan que en vez de adoptar un marco común para entender esta amenaza, "los actores redoblan sus críticas a la globalización y al neoliberalismo [...] Los observadores políticos ven la pandemia como una perfecta ilustración de las ventajas o defectos del autoritarismo o la democracia; elija su veneno" (Roberts y Lamp, 2020).

Desde 2009 se han declarado cinco emergencias internacionales de salud pública: por la gripe porcina en 2009, el brote de polio en 2014, el brote de ébola en África Occidental en 2014, el brote de Zika en 
2015 y otro brote de ébola en la República Democrática del Congo en 2019. Entre 2011 y 2018, la OMS detectó 1.483 episodios de epidemia en 172 países, y los calificó como signos de una nueva era de epidemias de gran impacto y rápida propagación. También advirtió sobre la amenaza totalmente creíble de un patógeno respiratorio que en provocaría una calamidad global que "podría cobrar entre 50 y 80 millones de vidas, y destruir hasta el 5\% de la economía mundial, además de causar inestabilidad social y política" (Turzi, 2020).

\section{BÚSQUEDA DE DATOS CIENTÍFICOS}

En la era de Internet y rápidas redes sociales, la opinión mundial ha consumido mucha información errónea y desinformación sobre el virus e interiorizado un temor y una ansiedad profundos. Se ha alegado la existencia de "laboratorios secretos", de "complots gubernamentales" y de "manipulación" del virus en la competencia geoeconómica entre Estados Unidos y China, así como una posible conspiración contra Irán. E1 16 de marzo, el número de muertes en Irán superó las 850, incluida la del ayatola Hashem Bathayi Golpayegani, miembro del grupo clerical que nombra al líder supremo, luego de dar positivo por coronavirus y ser hospitalizado.

El pánico general ha ayudado a vender información alarmista. Samuel Scarpino, profesor de Ciencias Ambientales en Northeastern University, señala: "El vínculo entre contagios sociales y contagios biológicos reales es una característica de los brotes modernos debido a la desinformación y las noticias falsas". Hasta ahora han circulado dos narrativas dominantes: China "fabricó" el virus y Estados Unidos "inició" el brote deliberadamente. Philip Reeker, alto funcionario del Departamento de Estado, dijo que actores rusos "malignos" intentaban sembrar desinformación sobre el origen del coronavirus.

La comprensión pública del coronavirus se puede dividir en dos categorías principales: una científica y una que interpreta ciertos incidentes. Desde la perspectiva científica, un reciente estudio realizado en Borneo y China puso bajo nueva luz el brote de coronavirus en China. Científicos que trabajan con EcoHealth Alliance, un grupo de investigación sin ánimo de lucro, concluyeron que la pandemia era un "desbordamiento", un caso en que un virus animal salta a un ser humano. E1 ecólogo de enfermedades Kevin Olival y sus colegas recogieron muestras de miles de murciélagos en China. Olival explicó que "en total, de todos los muestreos que hicimos en China encontramos evidencia de cerca de 400 nuevas cepas de coronavirus" 
(Aizenman, 2020). Se sabe que los murciélagos portan algunos que son peligrosos, en particular virus con potencial para desencadenar brotes globales (ibíd.). Uno de los coronavirus que encontraron estos investigadores era genéticamente muy cercano al virus del SARS.

Otra ecóloga de EcoHealth Alliance, Hongying Li, destacó que de muchas maneras las personas pueden estar en riesgo de entrar inadvertidamente en contacto con saliva, orina o heces de los murciélagos. Ella dijo: "En algunos lugares se encuentran murciélagos que duermen en los hogares. Muchas personas informaron, 'Una vez entró en mi casa un murciélago y lo maté' o 'Los murciélagos se comieron las frutas de mi patio" (ibíd.). Investigadores del Instituto de Virología de Wuhan y del Hospital Jinyintan, que han trabajado en estrecha colaboración con EcoHealth Alliance, compararon el nuevo virus con muestras de murciélagos que recolectaron. Encontraron un parecido muy cercano, y publicaron un artículo detallado que muestra que la composición genética del nuevo coronavirus es "96\% idéntica a la de un coronavirus que se encuentra en los murciélagos" (ibíd.).

A pesar de la supuesta contención del virus en Wuhan, en China no hay un remedio claro, aunque los científicos se apresuran a encontrar una vacuna eficaz. Las autoridades chinas han defendido el uso de remedios tradicionales. Según el Ministerio de Ciencia y Tecnología, a los pacientes se les da una bolsa de sopa marrón; un remedio tradicional chino que mezcla más de 20 hierbas, incluidas efedra, ramas de canela y raíz de regaliz, junto con los principales medicamentos antivirales. Un equipo de expertos del Imperial College de Londres publicó un nuevo documento y advirtió que la actual amenaza a la salud pública es la "más grave", causada por un virus respiratorio, desde la gripe española en 1918. Y aconsejó que el gobierno del Reino Unido adoptara una estrategia de "supresión epidémica" -durante un periodo de unos 18 meses o más- en vez de una de "mitigación”. Con la estrategia de mitigación la capacidad del Servicio de Salud Británico "podría ser superada en al menos ocho veces y podrían morir unas 250.000 personas” (Heffer, 2020).

En Estados Unidos, el Centro para el Control y la Prevención de Enfermedades (CDC) afirma que los coronavirus son "una gran familia de virus comunes en las personas y muchas especies de animales: camellos, ganado, gatos y murciélagos. En raras ocasiones, los coronavirus animales pueden infectar a las personas y luego propagarse entre ellas, como el MERS-CoV, el SARS-CoV y ahora este nuevo virus, llamado 'SARS-CoV-2', un betacoronavirus, como el MERS$\mathrm{CoV}$ y el SARS-CoV. Estos tres virus tienen su origen en los mur- 
ciélagos" (CDC, 2020). Los CDC también concluyeron que "esta es la primera pandemia conocida causada por la aparición de un nuevo coronavirus. En el siglo pasado hubo cuatro pandemias causadas por la aparición de nuevos virus de la influenza" (ibíd.).

E1 Dr. William Schaffner, profesor de la Facultad de Medicina de la Universidad de Vanderbilt y desde hace tiempo asesor de los CDC, señala dos factores que han acentuado la propagación del coronavirus: "transmisión asintomática y transmisión levemente sintomática"; a los que considera "impulsores de la propagación en la comunidad" (Cohen, 2020). Otros científicos estiman la letalidad del coronavirus en un $2 \%$, en comparación con el $10 \%$ del SARS. Sin embargo, Joseph V. Micallef, historiador militar y escritor sobre asuntos mundiales, destaca que este virus no se encontró nunca antes. Y señaló: "Igual que otros coronavirus, es una enfermedad zoonótica: una enfermedad infecciosa causada por bacterias, virus y parásitos que se transmiten de animales no humanos (en general vertebrados) a los humanos. Muchos de los primeros infectados trabajaban o solían comprar en el mercado mayorista de mariscos de Wuhan" (Micallef, 2020).

\section{INTERPRETACIONES CONSPIRATIVAS}

Varias obras literarias se han vuelto centro de atención en el pico de la pandemia. Una de ellas es Los ojos de la oscuridad, publicado en 1981. $\mathrm{Su}$ autor, Dean Koontz, menciona un virus mortal llamado "Wuhan 400", al que describió como una "enfermedad grave parecida a una neumonía" que se propaga atacando "los pulmones y los bronquios" y "que resiste todo tratamiento conocido" (Ives, 2020). Dombey, uno de los principales personajes de la novela, narra la historia de un científico chino que llevó a Estados Unidos un arma biológica llamada "Wuhan-400": "Para entender eso", dijo Dombey, "hay que retroceder veinte meses. Fue entonces que un científico chino llamado Li Chen desertó a Estados Unidos, portando un registro en disquete de la nueva arma biológica más importante y peligrosa de China en una década. Lo llamó 'Wuhan-400' porque se desarrolló en los laboratorios de RDNA de las afueras de Wuhan, y fue la cepa viable número 400 de microorganismos creados en ese centro de investigación".

Cabe destacar la distancia entre ficción y realidad. Pero ciertos observadores políticos de China y funcionarios militares occidentales sostienen que hay un fuerte vínculo entre el coronavirus y una reciente investigación realizada en el Instituto de Virología de Wuhan. Otros argumentan que el coronavirus es una cosa y que los "secretos oscuros", 
que se desarrollan en los laboratorios de guerra biológica de todo el mundo son algo muy distinto. Además, en medios y publicaciones occidentales se tiende a dar un sentido étnico al nuevo virus calificándolo como el "virus chino".

La oficina de la OMS en China oyó los primeros informes de un virus desconocido como causa de casos de neumonía en Wuhan el 31 de diciembre de 2019. La narrativa principal luego aludió a la posibilidad de que el virus se podía haber originado en un mercado de mariscos de Wuhan, donde se comerciaban ilegalmente animales salvajes como marmotas, aves, conejos, murciélagos y serpientes. Después de reunirse con Tedros A. Ghebreyesus, Director General de la OMS, en el Gran Salón del Pueblo en la Plaza Tiananmen de Beijing, el presidente chino Xi Jinping declaró el 28 de enero de 2020: "la epidemia es un demonio. No podemos dejar que el demonio se esconda" (Spinney, 2020). E1 15 de febrero, el Ministerio de Ciencia y Tecnología publicó una nueva directiva titulada: "Instrucciones para fortalecer la bioseguridad en laboratorios de microbiología que manejan virus avanzados como el nuevo coronavirus". E1 11 de marzo las autoridades sanitarias chinas reconocieron más de 81.032 casos y 3.204 muertes.

Steven Mosher, presidente del Population Research Institute y autor de Bully of Asia: Why China "dream" is the new threat to world order, es escéptico acerca de lo que está detrás del urgente llamado de Xi Jinping -una semana después de su declaración sobre "la necesidad de contener el coronavirus" el 15 de febrero- para establecer un sistema nacional de control de riesgos de bioseguridad "que proteja la salud de la gente", pues la seguridad de los laboratorios es un tema de "seguridad nacional". También cree que China tuvo problemas "para mantener los patógenos peligrosos en los tubos de ensayo a los que pertenecen. ¿Cuántos laboratorios de microbiología que manejan 'virus avanzados como el nuevo coronavirus' existen en China?" (Mosher, 2020). Mosher razona en forma deductiva que Wuhan es el lugar de nacimiento del coronavirus, y argumenta: "En toda China solo hay uno. Y está ubicado en Wuhan... el epicentro de la epidemia. Así es. El único laboratorio de microbiología de nivel 4 de China equipado para manejar coronavirus mortales, llamado Laboratorio Nacional de Bioseguridad, es parte del Instituto de Virología de Wuhan” (ibíd.).

Los informes indican que el principal experto en guerra biológica del Ejército Popular de Liberación, el mayor general Chen Wei, fue enviado a Wuhan a fines de enero para ayudar en el esfuerzo de contener el brote. Según el PLA Daily, Chen investiga coronavirus desde 
el brote de SARS de 2003, así como el ébola y el ántrax. Este no sería su primer viaje al Instituto de Virología de Wuhan, ya que es uno de los dos únicos laboratorios de investigación de armas biológicas en toda China. Mosher sostiene que el virus mortal del SARS se ha escapado dos veces del laboratorio de Beijing; y que las epidemias del coronavirus y del SARS "provocadas por el hombre" fueron contenidas rápidamente, pero que ninguna de ellas habría sucedido si se hubiesen tomado las precauciones de seguridad adecuadas.

Ivo Daalder, presidente del Consejo de Asuntos Globales de Chicago y ex embajador de Estados Unidos en la OTAN, critica a China por su "secretismo y su inacción", que convirtieron la posibilidad de una epidemia en realidad (Daalder, 2020). Recuerda que a finales de diciembre de 2019 los médicos de Wuhan, una ciudad industrial de 11 millones de personas, observaron un aumento del número de personas enfermas con síntomas similares al brote de SARS que mató a casi 800 personas en 2002-2003. A los pacientes se los puso en cuarentena, y la comisión de salud de Wuhan emitió un aviso público que no destacaba motivos de alarma. Las infecciones se rastrearon hasta un mercado de alimentos y animales vivos, que se cerró el 1 de enero; dos días después se identificó la secuencia genética de un nuevo coronavirus.

$\mathrm{El}$ artículo de Daalder provocó alboroto entre los funcionarios chinos. Zhao Jian, cónsul general de China en Chicago, envió una carta al editor del Chicago Tribune, en la que acusó a Daalder de “inexactitudes y prejuicios" (Timsit, 2020). La diplomacia china se ha movilizado en Occidente para controlar esa narrativa y promover la idea de que la respuesta del Partido Comunista al brote fue transparente y eficaz. La embajada en Londres acusó a The Economist de "tener prejuicios contra el sistema político chino". En París, la embajada dijo que en algunos medios de comunicación "la crítica de todo lo chino roza la paranoia”. En Berlín, diplomáticos chinos acusaron a los medios de "provocar y sembrar pánico". Irónicamente, la embajada en Copenhague exigió que el Jutland Post, el periódico más vendido en Dinamarca, "se disculpe públicamente con el pueblo chino" por publicar una caricatura que muestra una bandera china con ilustraciones de un virus en vez de estrellas (ibíd.).

Los observadores occidentales han mostrado escepticismo sobre el secreto excesivo de China acerca de la dinámica de propagación del coronavirus y la movilización masiva de interlocutores para imponer una narrativa oficial, pero menos creíble. Lucrezia Poggetti, analista de las relaciones entre la UE y China en el Instituto Mercator de 
Estudios de China, señala que "el Partido Comunista tomó drásticas medidas por compartir información sobre la enfermedad y envió a más de 300 personas para elaborar noticias positivas sobre el brote” (ibíd.). Otros han advertido la falta de información de China. Por ejemplo, Anthony Fauci, director del Instituto Nacional de Alergias y Enfermedades Infecciosas de Estados Unidos, señaló el vacío y cuestionó la diferencia entre "las cifras que se dan en una conferencia de prensa y las cifras que se pueden ver realmente en los datos".

\section{VACUNA ANTI CORONAVIRUS Y ELECTORERISMO TRUMPIANO}

En un giro interesante en la campaña mundial contra la pandemia, la ciencia de los virus se ha convertido en una nueva batalla de conocimiento y fuga de cerebros, y en un nuevo campo de especulación para Donald Trump. Miembros del gobierno alemán han manifestado resentimiento por la noticia de que el presidente Trump ofreció mil millones de dólares a CureVac, empresa biofarmacéutica con sede en Tubinga, para asegurar la vacuna "solo para Estados Unidos” (The Guardian, 2020). CureVac se fundó en 2000 y se especializa en "desarrollo de tratamientos contra el cáncer, terapias con anticuerpos, tratamiento de enfermedades raras y vacunas profilácticas" (ibíd.).

Christian Lindner, líder del partido liberal FDP, acusó al presidente Trump de ser electorero: "Obviamente, Trump usará todo medio disponible en la campaña electoral”. El ministro de Economía alemán, Peter Altmaier, declaró: "Alemania no está en venta”. Su colega, el ministro de Relaciones Exteriores, Heiko Maas, dijo a la red de investigación Funke Mediengruppe: "Los investigadores alemanes están tomando un papel de liderazgo en el desarrollo de medicamentos y vacunas como parte de las redes de cooperación global. No podemos permitir que otros quieran adquirir exclusivamente los resultados de sus investigaciones" (ibíd).

Washington ha intentado calmar el alboroto. Un funcionario estadounidense declaró: "el gobierno estadounidense ha hablado con muchas [más de 25] empresas que pueden ayudar con una vacuna. La mayoría ya recibió financiación inicial de inversionistas estadounidenses" (ibíd.). Los inversionistas de CureVac decidieron no vender el vacuna a un solo Estado; y el principal inversionista, el holding Hppp BioTech, declaró; "Si tenemos éxito en el desarrollo de una vacuna eficaz, debería ayudar y proteger a las personas de todo el mundo". El fin electorero de Trump de conseguir una vacuna contra el coronavirus 
ha acentuado los rumores sobre la posible producción deliberada del virus en un laboratorio con objetivos estratégicos.

Hasta ahora han surgido algunas noticias prometedoras sobre un posible avance en el diseño de un medicamento para combatir la pandemia. El Ministerio de Ciencia y Tecnología de China anunció que un nuevo fármaco conocido como Favipiravir, desarrollado por una subsidiaria de la japonesa Fujifilm Toyama Chemical, tuvo resultados alentadores en ensayos clínicos con 340 pacientes en Wuhan y Shenzhen. En Australia, expertos en enfermedades de la Universidad de Queensland en Brisbane están entusiasmados con dos medicamentos existentes que erradicarían la infección de coronavirus: la cloroquina, un medicamento contra la malaria, y una combinación de lopinavir y ritonavir que suprime el VIH.

No hay ninguna certeza sobre la validez de estos experimentos médicos, mientras que 35 empresas e instituciones académicas compiten por crear una posible vacuna. La sabiduría común entre la mayoría de expertos médicos es la mera esperanza de que el desarrollo de tal vacuna requiera entre 12 y 18 meses. Trump ha presionado para que esté lista en noviembre, la fecha límite de las elecciones presidenciales. Pero es un plazo imposible. Annelies Wilder-Smith, profesora de enfermedades infecciosas emergentes en la Escuela de Higiene y Medicina Tropical de Londres explica: "Como la mayoría de los expertos, no creo que esta vacuna esté lista antes de 18 meses”.

\section{II}

\section{ECONOMÍA DEL GOTEO DEL CORONAVIRUS}

E1 16 de marzo, los mercados financieros mundiales, incluido Wall Street, sufrieron un baño de sangre cuando el promedio del Dow Jones industrial cayó cerca del 13\%, el peor porcentaje de pérdida desde el colapso del Lunes Negro de 1987. Cuatro días antes, el mercado de valores de Estados Unidos eliminó los 11,5 billones de dólares de valor que ganó desde la victoria electoral de Trump en 2016. El otrora gregario presidente, que dijo a sus compatriotas: "E1 coronavirus desaparecerá. Solo mantengan la calma”, se enteró de que "tenemos un enemigo invisible". Reconoció que el virus podía llevar a Estados Unidos a una recesión. "Esto es malo. Muy malo" (White, 2020). Trump parece enfrentarse a los ecos de 1929 en la crisis envolvente del coronavirus. Algunos analistas dijeron que es de nuevo el Lunes Negro; y predijeron "una escala de daño jamás vista en la economía moderna de Estados Unidos: un potencial de millones de 
empleos perdidos en un solo mes, una caída histórica y repentina en la actividad económica de todo el país y un ritmo de cambios bruscos del mercado no visto desde la Gran Depresión" (ibíd.).

El profesor de economía de Yale y premio Nobel de 2013, Robert Shiller, ha escrito sobre las narrativas que afectan la economía. Dice que el coronavirus es "una situación muy inusual. Hace solo unos meses la gente no anticipaba que algo así podía ocurrir: que en estos tiempos modernos podíamos tener una grave epidemia y que el gobierno estaría luchando para contenerla" (Detrixhe, 2020). Estos cambios negativos impulsados por el coronavirus suscitan nuevas preguntas sobre la política económica de la administración Trump, guiada por la teoría del goteo. La economía del goteo, conocida como Reaganomics, fue celebrada como salvadora de Occidente en la recesión de 1980 durante la época de Reagan. Al adoptar beneficios como recortes de impuestos a empresas, personas de altos ingresos, ganancias de capital y dividendos, esa política afirma que los beneficios a los ricos llegan a los demás miembros de la sociedad.

La esencia de tal afirmación oscurece la diferencia entre el pragmatismo de la ciencia y la falacia de la ideología capitalista. En su primer año en el cargo, Trump firmó la Ley de Empleos y Reducción de Impuestos, que redujo la tasa de impuestos corporativos del 35\% al 21\% a partir de 2018. La tasa individual máxima cayó al 37\%. E1 plan fiscal de Trump recortó las tasas del impuesto de renta, duplicó la deducción estándar y eliminó las exenciones personales. Los recortes corporativos son permanentes mientras que los cambios individuales expiran a finales de 2025 (Amadeo, 2019). En la primera semana de marzo de 2020, los líderes de los principales bancos de Wall Street fueron convocados a la Casa Blanca para discutir las consecuencias económicas del coronavirus. Se anuncia que Trump considera más recortes de impuestos corporativos, a las aerolíneas y la industria hotelera, y un recorte temporal del impuesto a la nómina. La Casa Blanca piensa solicitar al Congreso la aprobación de un paquete de estímulo de 850 mil millones de dólares para estabilizar la economía y de otros mil millones para ayudar a las aerolíneas. El plan también incluye otros 100 mil millones de dólares para programas de pagos de licencias por enfermedad, asistencia alimentaria y otras ayudas a los trabajadores estadounidenses. La asignación financiera total solicitada para hacer frente al coronavirus puede superar un billón de dólares.

Otros países consideran generosos paquetes gubernamentales para estimular su economía local. Gran Bretaña lanzó un plan de estímulo económico de 39.000 millones de dólares horas después de que el 
Banco de Inglaterra recortara las tasas de interés. Italia adoptó un paquete de 28.000 millones de dólares para garantizar que empresas y trabajadores reciban ayuda durante la crisis. Qatar asignó un paquete de estímulo de 23.350 millones para proteger su economía. China destinó 15.900 millones para combatir la epidemia. Estos son algunos de los remedios financieros mejor concebidos para enfrentar las ramificaciones de una pandemia imparable. Pero solo tienen el efecto de corta duración de una aspirina para calmar un dolor de cabeza económico de largo plazo.

Soy escéptico de que estas medidas de goteo resuelvan el problema. La verticalidad del enfoque del goteo, o de estímulos similares a las grandes empresas privadas, no coincidirá con la gran horizontalidad de la recesión económica derivada del coronavirus. La pandemia ha aplastado empresas públicas y privadas enteras y ha afectado tanto a la oferta como a la demanda. Metafóricamente, el motor económico mundial perdió energía se súbito y quedó inactivo a mediados de marzo, con alarmantes medidas de precaución y aislamiento sin fin. Además, es probable que el impacto de la pandemia refuerce y profundice la tendencia a políticas de puertas cerradas, desconfianza, disociación y desglobalización. Refuerza la incertidumbre y augura la desaparición de la OMC, como uno de los puntos de inflexión hacia la desglobalización, así como el ascenso del nacionalismo, el populismo, el proteccionismo y la reacción contra la migración.

La pandemia detuvo todos los engranajes de la economía, las manufacturas, los centros comerciales, las aerolíneas, los hoteles y los mundos Disney. Muchas ciudades están en aislamiento y la gente se queda en casa. No va a restaurantes ni a a centros comerciales, no viaja ni compra autos. A la economía mundial la afectan el estancamiento y el aislamiento. Por ejemplo, el 70\% de la economía estadounidense es impulsada por el gasto de los consumidores y ha estado en un cierre sin precedentes. Es improbable que la mayoría de las economías puedan evitar una recesión a corto plazo. Un gran número de empresas irá a la quiebra; y la clase media perderá parte de su capacidad financiera una vez más. Los duros efectos de la pandemia se revelarán cuando las personas puedan volver al trabajo, salir y gastar dinero en unos meses. Un modelo de Bloomberg Economics estima en un 52\% la probabilidad de una recesión en el próximo año, la mayor desde 2009. John Normand de JP Morgan dijo que los mercados financieros de activos estiman en un $80 \%$ la probabilidad de que ocurra una recesión. 
Sigue sin resolver la cuestión de cuánto tiempo se necesitará para que los consumidores y las empresas recuperen la confianza. Esta es una época de incertidumbre y perplejidad por excelencia. Algunos expertos en finanzas predicen que las ramificaciones de la pandemia no se revertirán hasta 2031. Por ejemplo, economistas de Goldman Sachs declararon que la economía de Estados Unidos estaba a prueba de recesión a comienzos de 2020. Alan Blinder, ex vicepresidente de la Reserva Federal y hoy profesor en Princeton, dice: "Poco me sorprendería si cuando veamos los datos hacia atrás, se decidiera [...] que la recesión empezó en marzo. No me sorprendería”(Lewis, 2020).

Robert Reich, profesor de Política Pública en la Universidad de California en Berkeley y ex secretario de Trabajo en la administración Clinton, cree que las medidas de Trump serán “inútiles”.

Serán demasiado lentas para estimular la economía y no llegarán a los hogares y consumidores, que deberían ser los objetivos reales. Y recompensarán a los ricos, que no gastan gran parte de sus dólares adicionales, sin poner dinero en manos de los pobres y de la clase media, que sí los gastan (Reich, 2020).

Para enfrentar la crisis económica, el gobierno necesita una visión pragmática que evite las pérdidas económicas de las clases baja y media. Reich pidió al Congreso que promulgue de inmediato una emergencia de 400.000 millones de dólares. Y recomienda que el dinero se gaste en áreas clave: a) Pruebas y tratamiento del coronavirus, b) Licencia remunerada por enfermedad y familiar este año, renovable el próximo año si es necesario, c) Seguro de desempleo y Medicaid extendido, y d) Pagos únicos inmediatos de mil dólares por adulto y 500 por niño, renovables el próximo año si es necesario.

Otros economistas argumentan que la pandemia puede ser "lo más positivo" que le haya ocurrido a la economía global en los últimos años. Peter Zeihan, autor de Naciones desunidas: la lucha por el poder en un mundo sin gobierno, cree que China es el taller del mundo.

En términos absolutos, China es, con mucho, el mayor beneficiario de este orden dirigido por Estados Unidos. Japón y los europeos dividieron el territorio chino en esferas de influencia imperiales. Los estadounidenses terminaron con eso. La destreza manufacturera de China requería que las economías de escala de toda China estuvieran bajo un sistema de gobierno único (Zeihan, 2020).

No se deben considerar únicamente las ramificaciones del cierre por la pandemia, también hay que tener en cuenta la correlación con la disputa ruso-saudí sobre precios y producción de petróleo, que en esencia equivale a verter gasolina sobre una llama. En la última semana 
de febrero, OPEP, un cartel de 15 países productores, se reunieron en Viena para discutir cómo enfrentar el impacto de la enfermedad, que redujo la demanda mundial de petróleo. Rusia fue invitada a la reunión aunque no es miembro oficial de la organización; pero hace tres años prometió coordinar su nivel de producción con los 15 miembros, en una alianza conocida como OPEP+.

Entre Moscú y Riad hay temas pendientes sobre un recorte razonable de la producción de petróleo. Arabia Saudita, líder del cartel, sugirió que los participantes recortaran colectivamente su producción en cerca de un millón de barriles-día. Sin embargo, Rusia, recelosa ante el plan, aceptó hasta 500.000 barriles-día. Se dice que el Kremlin quiere mantener un bajo nivel de precios, que "perjudicaría a la industria estadounidense del petróleo de esquistos, o se prepara para aprovechar una parte mayor de la demanda de petróleo asiática y mundial”. Emma Ashford, experta del Instituto CATO, dice que "los rusos están más preocupados por la participación de mercado y creen que competirían mejor con los saudíes, en vez de cooperar en este momento" (Ward, 2020). La estrategia rusa no ha funcionado bien con los saudíes, que a comienzos de marzo decidieron recortar aún más sus exportaciones para librar una guerra de precios con $\mathrm{Ru}-$ sia. E1 precio por barril bajó alrededor en cerca de 11 dólares a 35, la mayor caída diaria desde 1991.

El coronavirus indujo una apertura epistemológica a la ciencia de las epidemias y pandemias. La Wharton School de la Universidad de Pensilvania of rece un nuevo curso sobre coronavirus y otros brotes de cisne negro. Uno de los objetivos de la clase "Epidemias, desastres naturales y geopolítica: gestión de la incertidumbre financiera y empresarial global" es aportar "conocimientos especializados a inversionistas, trabajadores, consumidores y ahorradores sobre cómo afrontar estas crisis, para que estén mejor informados y puedan tomar mejores decisiones”, dijo Mauro Guillén, profesor de gestión internacional y coordinador de la clase. El curso, de medio semestre, empieza el 25 de marzo y ha demostrado ser popular: ya se inscribieron 450 estudiantes, casi un 5\% más que en una clase típica de Wharton. Paul Krugman inició una serie de lecciones magistrales "Economía y Sociedad" en línea, con una suscripción inicial de 15 dólares; Su objetivo es enseñar los principios que enmarcan problemas políticos y sociales, como el acceso a atención médica, el debate fiscal, la globalización y la polarización política. Krugman argumenta que la economía no es un conjunto de respuestas: "es una forma de entender el mundo". 


\section{POLITIZACIÓN DEL CORONAVIRUS EN LAS RELACIONES INTERNACIONALES}

No es extraño que las epidemias y las pandemias se hayan manipulado políticamente a lo largo de la historia. A menudo han impulsado llamamientos de los políticos de derecha a vigilar las fronteras y bloquear la migración. Por ejemplo, en el siglo XVIII la monarquía Habsburgo del Imperio Austro-Húngaro erigió un cordón sanitario desde el Danubio hasta los Balcanes, en forma de una cadena de fortalezas, con el supuesto fin de detener la entrada de infecciones desde el imperio otomano. También sirvió como frontera militar, económica y religiosa, como línea de demarcación entre el cristianismo y el Islam, patrullada por campesinos armados que enviaban los sospechosos de infección a estaciones de cuarentena construidas en toda su extensión (Spinney, 2020).

E1 actual debate político en Europa y Estados Unidos sobre el coronavirus hace eco al aislacionismo y la política de "puertas cerradas". Estadounidenses de mentalidad trumpiana y euroescépticos capitalizan el temor a la pandemia para imponer más barreras y seguridad fronteriza. Mientras impugnan la inmigración y el terrorismo, los políticos populistas de derecha argumentan que el coronavirus reivindica la preocupación por la necesidad de proteger las fronteras de su país. Dicen que la amenaza es "extranjera y que la respuesta es construir muros y detener los vuelos. En esta narrativa, la globalización acelera la amenaza" (Roberts y Lamp, 2020).

En Francia, Marine Le Pen, líder de Agrupación Nacional, de extrema derecha, antes conocida como Frente Nacional, pidió cerrar la frontera con Italia. Después de reunirse con el primer ministro Edouard Philippe, dijo a los periodistas: "Estoy pidiendo el control de nuestras fronteras. Parecería que pido la luna cuando, de hecho, hacer controles en las fronteras debería ser el primer acto de sentido común”. Su colega Aurelia Beigneux advirtió: “La libre circulación de mercancías y personas, las políticas de inmigración y el débil control de las fronteras permiten obviamente la propagación exponencial de este tipo de virus. Las ciudades globales hiperconectadas pueden ser fuerzas económicas imponentes, pero también son puertos de entrada para la infección. Vivir en un 'Estado elevado' es una posición envidiable" (ibíd.). La primera vuelta de las elecciones locales en Francia, celebrada el 15 de marzo, estuvo marcada por una atmósfera inquietante de semi-cierre y pandemia global, que llevó a una abstención récord. Nacionalistas de Europa como el primer ministro de 
Hungría, Viktor Orban, se habían quejado de que Europa no podía tener fronteras internas abiertas si sus fronteras externas eran débiles y permitían entrar sin control a quienes solicitaban asilo. Lorenzo Quadri de la derechista Liga de Ticino en Suiza, que no es miembro de la UE, ha pedido una política de "puertas cerradas". Argumenta que "es alarmante que el dogma de fronteras abiertas se considere una prioridad". Este es un matrimonio celestial entre la política de derecha y el miedo a la nueva pandemia.

El ascenso del nacionalismo puede poner fin a la ya frágil unidad de la UE del sistema Schengen, mientras que el debate entre europeos sobre la "sabiduría" del Brexit aún no se ha resuelto. Nueve países, incluidos Alemania y Francia, han adoptado medidas de emergencia para restablecer algunos controles en diferentes momentos (Laurent, 2020). Marie de Somer, jefa del programa de migración del Centro de Políticas Europeas con sede en Bruselas, señala que "Schengen está en una situación mala y problemática”, y que el restablecimiento de su plena funcionalidad depende de que "se modifiquen las reglas de asilo y migración del bloque" (ibíd.). En retrospectiva, regímenes autoritarios como China han capitalizado el estallido de varias epidemias y pandemias. Los líderes chinos se han jactado de su capacidad "para vencer la enfermedad como signo de fortaleza. El presidente $\mathrm{Xi}$ ha concentrado el poder a su alrededor, lo que lo convierte en el blanco más probable de culpabilidad para una población enojada y atemorizada si el experimento falla. Quizás por ello hace poco se retiró de la mirada pública, dejando ver sus lugartenientes manejan la situación" (Spinney, 2020).

La cobertura de la pandemia en los medios de comunicación mundiales ha situado a China como un inconforme con la narrativa pospandemia y ha fortalecido su búsqueda de liderazgo mundial. Pekín busca ganar terreno con su 'exitosa' derrota del virus asumiendo el liderazgo en la ayuda a Italia y España, y capitalizando las insuficiencias observadas y el enfoque de la política estadounidense. También ha intentado replantear la narrativa porque el brote se interpretó como un desastre propagandístico para el gobierno. China temía que el coronavirus se llamara el "Chernobyl" de China y que, en últimas, socavara el liderazgo del Partido Comunista. Los informes indican que el Dr. Li Wenliang, el joven denunciante silenciado por el gobierno que luego sucumbió a las complicaciones de la COVID-19, fue comparado con el "hombre del tanque" de la Plaza de Tiananmén (Campbell y Doshi, 2020). 
A mediados de marzo, China reclamó la victoria. "Las cuarentenas masivas, la interrupción de los viajes y el cierre total de la mayor parte de la vida cotidiana en todo el país fueron acreditados por haber frenado la marea"; "la fuerza, eficiencia y velocidad características de China en esta lucha han sido ampliamente aclamadas", declaró el portavoz del Ministerio de Relaciones Exteriores Zhao Lijian. (ibíd.). Un artículo de opinión publicado por la agencia de noticias estatal Xinhua enfatizó que China adoptó "las medidas preventivas más exhaustivas, estrictas y completas" para combatir la pandemia. Con un tono nacionalista, el People's Daily se jactó de que "China puede reunir la imaginación y el coraje necesarios para manejar el virus, mientras Estados Unidos se esfuerza". Los funcionarios chinos aprovecharon la tensión causada por el coronavirus en Europa y Estados Unidos para recordar regularmente a la audiencia mundial la superioridad de los esfuerzos chinos y criticar la "irresponsabilidad e incompetencia" de la "élite política de Washington", como dijo la agencia de noticias estatal en un editorial (ibíd.).

Nicholas Christakis, profesor de Yale, expresó un sentimiento general cuando elogió a China por "un logro asombroso desde el punto de vista de la salud pública" (Rachman, 2020). La OMS ha elogiado el enfoque chino para controlar la propagación del coronavirus, $y$ ha alabado en exceso la diplomacia pública china y el poder blando; por enviar suministros médicos a España e Italia y ofrecer orientación a España, Irak, Irán y otros países. Su director general, Tedros A. Ghebreyesus, calificó la cooperación chino-italiana como un "ejemplo reconfortante de solidaridad". Zhang Jun, embajador de China en las Naciones Unidas, respondió: "un amigo necesitado es un amigo de hecho. Haremos todo lo posible para ayudar a otros países en la lucha contra la COVID-19". Los funcionarios chinos han convertido el coronavirus 'casero' en una mega oportunidad global de diplomacia pública. En resumen, la China autoritaria de 2020 está superando el poder blando de Estados Unidos en Europa, reconstruido por el Plan Marshal después de la Segunda Guerra Mundial. Beijing ha tenido una oportunidad histórica para ser líder mundial en salud pública y está lista para asumir otros tipos de liderazgo mundial.

\section{¡NEOLIBERALISMO AVERGONZADO EN UN MOMENTO DE LA VERDAD!}

Con el creciente alcance de las implicaciones económicas y sanitarias de la pandemia, la humanidad se desliza cuesta abajo en 2020. El 
famoso mantra laissez passer, laissez faire se ha transformado dramáticamente en rester chez soi, mourir chez soi (quédate en casa, muere en casa). Durante semanas, la escasez de pruebas de COVID-19 en Estados Unidos ha sido un dilema. CNN informó que muchos estadounidenses que tenían síntomas de la enfermedad estaban enojados y frustrados después de intentar hacerse la prueba y ser rechazados. El gobernador de Maryland, Larry Hogan, captó el desafío a nivel local y federal. Reconoció: "No, no tenemos suficientes kits de prueba; tampoco ningún otro estado, y el gobierno federal no tiene una respuesta. Estamos retrasados y eso seguirá siendo un problema". El sistema de salud pública de Estados Unidos se ha descarriado. Adam Gaffney, de la Facultad de Medicina de Harvard y presidente de Physicians for a National Health Program señaló: "Este no es un sistema de salud, es un caos atomizado. Pues, de nuevo, a la manera estadounidense de pagar la atención médica, nuestros hospitales (o cada vez más, nuestros sistemas multi-hospitalarios) son inconexos, sean ricos o pobres, y cada cual se vale por sí mismo encerrado en la competencia de mercado" (Gaffney, 2020). En Europa, Italia registra la tasa de mortalidad más alta y muchas de las víctimas son personas de 80 a 90 años. Según el New York Times, Italia tiene la población más anciana de Europa, con cerca de un 23\% de los residentes de 65 o más años, mientras que la edad promedio es de 47,3 años, frente a 38,3 en Estados Unidos.

Entre el trumpismo actual y el thatcherismo y el reaganismo de la década de 1980, se puede ver la transformación del neoliberalismo como cobertura de todo lo que evoca desregulación, liberalización, privatización o austeridad fiscal. El neoliberalismo se deriva de nociones que supuestamente se basan en el concepto de homo economicus, el ser humano perfectamente racional, sujeto de muchas teorías económicas, que siempre persigue su propio interés (Rodrik, 2020). El término "neoliberalismo" en francés apareció en 1898 en las obras del economista Charles Gide para describir las creencias económicas del economista italiano Maffeo Pantaleoni. Y cobró impulso en un encuentro intelectual internacional, el Coloquio Walter Lippmann, convocado por el filósofo francés Louis Rougier en París en 1938. Lippman, periodista estadounidense, escribió un libro muy leído, Una investigación sobre los principios de la buena sociedad, en 1937. El objetivo del coloquio era construir un nuevo liberalismo en rechazo del colectivismo, el socialismo y el liberalismo de laissez-faire. Definió el "neoliberalismo" como una visión que da prioridad "al mecanismo de precios, a la libre empresa, al 
sistema de competencia y a un Estado fuerte e imparcial" (Mirowski y Plehwe, 2009).

En un contexto posterior a la Segunda Guerra Mundial y de enfrentamiento capitalista-comunista de la Guerra Fría, Milton Friedman utilizó el término en su ensayo "El neoliberalismo y sus perspectivas". Rechazó lo que consideraba "una fe generalizada, aunque ingenua, incluso entre las clases intelectuales, en que la nacionalización remplazaría la producción con fines de lucro por la producción para el uso" (Friedman, 1951). También impugnó lo que veía como un colectivismo menguante, en una sutil referencia al socialismo y otras formas de socialdemocracia.

Es probable que el colectivismo resulte ser mucho más difícil de revertir o cambiar fundamentalmente que el laissez-faire, en especial si llega a socavar los fundamentos de la democracia política. Y esta tendencia, que estaría presente en cualquier caso, seguramente será radicalmente acelerada por la guerra fría y por la alternativa más terrible de una guerra a gran escala. Pero si estos obstáculos pueden superarse, el neoliberalismo ofrece una esperanza real de un futuro mejor, una esperanza que ya es una fuerte contracorriente de opinión y que puede captar el entusiasmo de los hombres de buena voluntad en todas partes y, por tanto, convertirse en la principal corriente de opinión (ibíd.).

E1 famoso dúo Thatcher-Reagan ejecutó bien su danza neoliberal. Durante su desafiante mandato como Primera Ministra, Thatcher presionó por una profunda transformación de la sociedad británica y fue la fuerza impulsora de la inserción de un motor neorrealista en las políticas públicas. Dejó el país como “un lugar muy diferente”. E1 neoliberalismo británico floreció "a través de un programa de recortes masivos de impuestos a los ricos; el aplastamiento de los sindicatos; la privatización de la vivienda, las telecomunicaciones, el acero y el gas; la desregulación financiera; y la introducción de la competencia en el provisión de servicios públicos" (Pearse, 2019). Al otro lado del Atlántico, la administración Reagan tuvo su momento dorado al liquidar el poder sindical y recortar el gasto público. El manierismo de Reagan en su discurso público ayudó a convencer a los estadounidenses con el mantra de la época: "la principal causa de nuestros problemas económicos ha sido el mismo gobierno".

En su ensayo "A Neo-Liberal's manifesto", Charles Peters, editor del Washington Monthly, elogió como como una "virtud" la forma en que los neoliberales posicionaron la búsqueda de la liberalización financiera y la empresa individual. Y explicó:

Si los neoconservadores son liberales que adoptaron una mirada crítica del liberalismo y decidieron convertirse en conservadores, somos liberales 
que adoptaron esa misma mirada y decidimos mantener nuestros objetivos, abandonando algunos de nuestros prejuicios [...] Nuestras principales preocupaciones son la comunidad, la democracia y la prosperidad. De ellas, el crecimiento económico es hoy la más importante, porque es esencial para casi todo lo demás que queremos lograr (Peters, 1982).

Pero toda tendencia neoliberal aboga por la "sabiduría" de cuatro pilares particulares: privatización, desregulación, mercados libres e individualización, como construcción antitética a la protección de los intereses de grupo. En las décadas siguientes el neoliberalismo fue adoptado no solo entre conservadores o republicanos de Occidente, sino también entre trabajadores y demócratas, incluido Bill Clinton. El ganador del Nobel Joseph Stiglitz sostiene que el capitalismo no tiene por qué producir desigualdad. Dice, en cambio, que la desigualdad es el resultado de las decisiones que toman los países capitalistas.

A finales de los noventa, el término "neoliberalismo" alcanzó dos desarrollos: la desregulación financiera, que culminaría en la crisis financiera de 2008 y en la aún persistente debacle del euro. El segundo fue la globalización económica, que aceleró un tipo de acuerdo comercial más ambicioso, en un mundo de libres flujos financieros. La financiarización y la globalización son las manifestaciones más evidentes del neoliberalismo en el mundo actual (Rodrik, 2017). David Harvey considera que el neoliberalismo es un "proyecto político" lanzado por la clase capitalista corporativa para "frenar el poder del trabajo" (Risager, 2016). Recuerda que el auge de los movimientos sociales, la protección del consumidor y otras iniciativas reformistas amenazaron los intereses de la clase dominante. $Y$ señala que esta clase "no era omnisciente, pero reconocía que había varios frentes en los que debía luchar: el ideológico, el político y, sobre todo, luchar para frenar el poder del trabajo por cualquier medio posible. De ahí surgió un proyecto político que yo llamaría neoliberalismo” (ibíd.).É1 cree que el proyecto político neoliberal no fue solo "un asalto ideológico" sino también "un asalto económico", y que "la clase capitalista corporativa lo puso en movimiento poco a poco" (ibíd.).

Otros escépticos del neorrealismo argumentan que las políticas públicas de Obama y Clinton, y su menosprecio por los ciudadanos vulnerables, llevaron a la elección de Donald Trump. Cornell West señala: "Nos preparamos para un futuro aterrador. La era neoliberal en Estados Unidos terminó con un estallido neofascista. El triunfo político de Donald Trump hizo añicos el establecimiento de los partidos demócrata y republicano, ambos ligados al gobierno del gran dinero y al reinado de políticos ampulosos"(West, 2016). West cree que la era 
de Obama fue el último aliento del neoliberalismo y argumenta que "a pesar de algunas palabras progresistas y gestos simbólicos, Obama optó por ignorar los crímenes de Wall Street, rechazar el rescate a los propietarios de vivienda, supervisar la creciente desigualdad y facilitar crímenes de guerra, como los drones estadounidenses que matan civiles inocentes en el extranjero" (ibíd.).

Desde una perspectiva 'normativa', el neoliberalismo puede afirmar que los principios de libre empresa e igualdad de oportunidades en el mercado, y la prosperidad potencial son la ley 'natural' del mercado. Esto se convirtió en lo que equivale a un posmodernismo de derecha. John Horgan, autor El fin de la ciencia, recuerda que el posmodernismo era popular entre ramas de la izquierda y la contracultura que asociaban la ciencia al capitalismo, el militarismo y otros malos ismos en las décadas de 1960 y 1970. Pero que "en las últimas décadas, el posmodernismo extremo, en especial la idea de que toda afirmación refleja los intereses del hablante, se ha vuelto aún más popular entre las de derecha" (Horgan, 2020).

Las políticas públicas neorrealistas se abrieron camino en Londres, Washington y más allá. La difusión del neoliberalismo surgió a través de la división ideológica entre derecha e izquierda, y a través de los grupos partidistas en la Cámara de los Comunes y el Congreso. Incluso los partidos nominalmente de izquierda, como el Partido Laborista del Reino Unido y el Partido Demócrata de Estados Unidos, eventualmente "claudicarían en sus prácticas, asimilando sus principios básicos" (Pearse, 2019). La ideología neorrealista también se instaló en entidades internacionales como el FMI, el Banco Mundial y la OM C, y se impuso a una escala sin precedentes en todo el mundo. La mayoría de los países en desarrollo aceptaron su liderazgo para implementar las reformas recomendadas. David Harvey recuerda que durante la crisis de la deuda mexicana en 1982, por ejemplo, el FMI dijo: "Te salvaremos". Lo que hicieron en realidad fue "salvar a los bancos de inversión de Nueva York e implementar una política de austeridad" (Risager, 2016). Algo similar sucedió en la reciente crisis de Grecia. Al final, "rescataron a los bancos e hicieron que la gente pagara mediante una política de austeridad" (ibíd.).

En Marruecos - uno de los países que desde comienzos de la década de 1980 adoptaron las recomendaciones de reformas neoliberales del FMI, conocidas como "programa de ajuste estructural"- los funcionarios decidieron

abandonar servicios públicos como la educación y la salud, privatizar empresas y entidades públicas, orientar la economía a la exportación, en par- 
ticular la agricultura, abrir el mercado marroquí a productos extranjeros y reducir las subvenciones a productos básicos como el trigo, el azúcar y el aceite, e incluso cancelar la subvención a la gasolina. Estas medidas se profundizaron mediante acuerdos comerciales aparentemente 'libres' firmados por Marruecos a mediados de los noventa (Moustakbal, 2017).

Dos décadas después surgieron fuertes contradicciones en la historia de los dos Marruecos resultantes, y desencadenaron intensas protestas:

un Marruecos de megaproyectos: puerto Tánger-Med, carreteras, trenes de alta velocidad, autos de lujo, villas, palacios y complejos turísticos con grandes piscinas y campos de golf. Y otro Marruecos, que ocupa un lugar muy bajo en el índice de desarrollo humano (IDH), oscilando en los lugares 126 a 130 entre 168 países durante los últimos años (ibíd.).

Estas políticas provocaron grandes desigualdades y malestar social entre los marroquíes, descontentos con el despotismo político del Majzen -la red de mecenazgo de la realeza, oficiales militares, terratenientes, funcionarios públicos y otros cercanos al Rey-, que "adopta casi todas las decisiones políticas y económicas en el país, con el neoliberalismo, el neocolonialismo, la privatización y el desarrollo orientado a la exportación y también con el cambio climático que ha causado sequías e inundaciones" (ibíd.). Hoy, los efectos de la pandemia y las limitaciones de las políticas neoliberales pueden socavar la vigencia del Comité Especial del Modelo de Desarrollo (CSMD), que Marruecos creó a finales de 2019 para consultar a los partidos políticos y los actores sociales. La composición del Comité la deciden tres figuras: Fouad Ali El Himma, asesor del Rey; Hafid Elalamy, ministro de Comercio; y Mostafa Terrab, presidente y consejero delegado de la empresa estatal marroquí de extracción de fosfato OCP. Se espera que el CSMD presente un informe a finales de junio de 2020, que identifique los desafíos para el crecimiento y diseñe políticas para garantizar una mejor distribución de la riqueza entre territorios y clases sociales. Lo más probable es que ese informe recurra a la política económica neoliberal vigente.

El neoliberalismo global puede vivir bajo una pátina de pragmatismo "hasta que empiecen a volar las armas nucleares o golpee un virus. Hacer que los 'consumidores' de atención médica consideren sus opciones de mercado es una lógica estrecha, pues ninguna de las opciones es relevante para una emergencia de salud pública [...] La premisa fundamental del neoliberalismo, la robinsonada, siempre ha sido una evasión cínica para dejar que los ricos se queden con el botín" (Urie, 2020). Por ejemplo, las políticas de Trump se escudan en la afirmación de que combinan políticas de intervención y no 
intervención del gobierno. Lily Roberts, directora de Movilidad Económica, y Andy Green, director de Política Económica del Center for American Progress, señalan:

La economía de Trump sigue presionando a los estadounidenses que luchan por llegar a fin de mes. A medida que los costos de alquiler, cuidado infantil, atención médica y educación postsecundaria aumentan más rápido que los salarios, la disminución de los ingresos y las persistentes brechas salariales y de riqueza ilustran que, para muchos estadounidenses, la capacidad de ahorrar para la jubilación o enviar sus hijos a la universidad está fuera de su alcance (Roberts y Green, 2019).

Hay una consecuencia aún mayor de la supremacía de la ideología. La pregunta es cómo el neoliberalismo ha reducido el poder del Estado, transfiriendo deliberadamente la autoridad a manos de "corporaciones transnacionales que no rinden cuentas. Los servicios fueron subcontratados; el mercado quedó a cargo. Este desarrollo demostró ser peligroso, ya que redujo la capacidad del gobierno para responder a las necesidades de su electorado. E1 desempoderamiento resultante, como lo ha experimentado la población, en muchos casos ha llevado a la privación del derecho al voto" (Pearse, 2019). Una vez más, las empresas estadounidenses y sus aliados multinacionales están listos para beneficiarse de los ingresos de la vacuna contra el coronavirus.

En su conferencia de prensa en la Casa Blanca, el secretario de Salud y Servicios Humanos de Estados Unidos, Alex Azar, cabildero de la industria farmacéutica y ex gerente de una compañía farmacéutica, mostró su comodidad con un sistema que antepone las ganancias corporativas a la salud pública. Dijo:

Francamente, esto tiene tanta atención mundial en este momento y los actores del mercado privado, los principales actores farmacéuticos, como han escuchado, están comprometidos en esto; creemos que no se trata de un tipo normal de procesos de adquisición, donde el gobierno podría ser el único comprador, digamos, de una terapia contra la viruela. Creemos que el mercado lo resolverá en términos de demanda, compras, almacenamiento, etc. Pero trabajaremos en eso para asegurarnos de que son capaces de acelerar la investigación y el desarrollo de vacunas y terapias (Sachs, 2020).

Aparentemente, los funcionarios de mentalidad neoliberal juegan la carta del cabildeo a favor de las empresas farmacéuticas y los laboratorios dominantes. El secretario Azar ha vuelto al libro de texto neoliberal y afirma que "el mercado realmente arreglará" el lío. ¡Sí, el mercado sagrado es el salvador! Estos políticos de derecha buscan imponer lo que se ha convertido en un diagnóstico irracional y allanar el camino, una vez más, para que las empresas farmacéuticas obten- 
gan grandes beneficios en los meses y años venideros. En una triste reflexión, el médico y profesor de Hawái, Seiji Yamada, señala que el coronavirus expone las vulnerabilidades que los humanos se crearon a sí mismos "comprando el programa neoliberal" (Yamada, 2020).

\section{EL CORONAVIRUS, LOS HUMANOS Y EL SISTEMA}

A lo largo de la historia, la democracia ha sido inútil en las epidemias. Igual que pandemias anteriores, la de COVID-19 interrumpió la vida pública en todo el mundo. Frank Snowden, profesor emérito de historia de la medicina en la Universidad de Yale, afirma:

No hay un área importante de la vida humana que las enfermedades epidémicas no hayan afectado profundamente. Las epidemias tienen efectos tremendos en la estabilidad social y política. Han determinado los resultados de guerras, y a veces pueden ser parte del inicio de guerras (Tharoor, 2020).

En las últimas dos décadas, los seres humanos han estado expuestos a oleadas de epidemias y pandemias rápida y oportunamente contenidas, como el SARS, el MERS, el ébola, la gripe porcina; así como a la del coronavirus. Es una forma macabra de replantear "cómo pensamos la historia humana: no como una sucesión de edades y épocas, sino de estertores apocalípticos y colapsos sociales"(ibíd.). Kurt M. Campbell, ex subsecretario de Estado para Asia y el Pacífico, y Thomas Wright, de la Brookings Institution, sostienen que "en la última década, el mundo se ha vuelto más autoritario, nacionalista, xenófobo, unilateralista, antisistema y opuesto al conocimiento. El estado actual de la política y de la geopolítica ha agravado la crisis, en vez de atenuarla (Wright y Campbell, 2020).

El sistema neoliberal logró su propósito en las últimas tres décadas, y los trabajadores desesperados no tuvieron más elección que "trabajar más y más duro. Y morir más jóvenes” (Urie, 2020). Si la pandemia persiste, hacia comienzos del verano de 2020 los trabajadores no podrán llegar a fin de mes o no tendrán oportunidades para compensar la pérdida de su fuente de ingresos. Un gran número de pequeñas empresas se verán forzadas a declararse en quiebra. En Occidente y en los países en desarrollo, el papel del Estado se ha reducido al de una agencia que regula el temor y prohíbe reuniones públicas. La OMS se ha convertido en una institución mundial de facto que no proporciona más que estadísticas de casos, muertes y propagación del coronavirus. Pero las pandemias y epidemias revelan "lo que importa realmente a la población, lo que está en juego y, en especial, a quién y qué valoran las sociedades" (Scott y Miller, 2020). Muchas organizaciones inter- 
nacionales no ofrecen más que operaciones de relaciones públicas. A mediados de marzo, la Cámara de Comercio Internacional (ICC) y la OMS acordaron trabajar en estrecha colaboración para garantizar que la información más reciente y confiable y una guía personalizada llegaran a la comunidad empresarial mundial. La ICC se comprometió a "enviar regularmente asesoramiento actualizado a su red de más de 45 millones de empresas para que las empresas de todo el mundo puedan tomar medidas informadas y eficaces para proteger a sus trabajadores, clientes y comunidades locales y contribuir a la producción y distribución de suministros esenciales" (WHO, 2020).

La lucha mundial contra el coronavirus puede ser un momento reflexivo y decisivo en la historia moderna. ¿Tenemos una red de seguridad de salud pública? ¿Cómo enfrentan los pobres el coronavirus? ¿Tenemos una estrategia para detener las epidemias cuando las grandes potencias se han excedido en el desarrollo de su capacidad de disuasión nuclear desde la Segunda Guerra Mundial? En la lucha contra el coronavirus, los estadounidenses también se están convirtiendo en daños colaterales. Se informa que la administración Trump está

muy mal preparada para tal empresa. No solo desconfió de las advertencias de la élite, debido a décadas de ataques conservadores contra el establishment intelectual, sino que el presidente no estaba dispuesto a creer en noticias que podían ser políticamente perjudiciales y estaba rodeado de un personal demasiado temeroso o incompetente para convencerlo de lo contrario. Ignoró los consejos de los expertos en salud pública que advirtieron que aumentaran las pruebas, ignoró las advertencias de los médicos de que las cosas estaban empeorando y no dijo a los estadounidenses que el distanciamiento social era necesario antes de que fuera muy tarde (Beauchamp, 2020).

Los historiadores de las pandemias se han visto impresionados por el hecho de que "cuanto más civilizados llegan a ser los humanos, con ciudades más grandes, rutas comerciales más exóticas y mayor contacto con diferentes poblaciones de personas, animales y ecosistemas, más probable es que haya pandemias" (LePan, 2020). El impacto del coronavirus, con el cierre de las sociedades en todo el mundo, cuestiona la premisa de las políticas neoliberales. Pide desmontar y desmitificar la ideología neoliberal que se disfraza de ciencia económica. En su ensayo "La peste neoliberal", Bob Uri advierte que la ignorante brutalidad de este sistema parece estar en camino de "hacer una revisión de la realidad a través de un virus diminuto" (Urie, 2020). Otras preguntas pertinentes se vislumbran en el horizonte: ¿qué debería ser primero: la sociedad o la economía, la salud pública o las ganancias, el bienestar de los ciudadanos o la plutocracia? ¿Es hora de un cambio de paradigma 
en la política pública? ¿Qué visión o visiones críticas nuevas surgirán de los restos del coronavirus? Sin duda, la promesa del Estado moderno y del "contrato social" de Westfalia ha sido decepcionante por la falta de una de las necesidades humanas básicas: la salud pública. Uno de las frases memorables de Thatcher aún resuena: "la sociedad no existe". Como resultado, los seres humanos se han reducido a competidores. William Pearse advierte: "Fríamente racional, incluso despiadado, el neoliberalismo ha enfrentado a las personas entre sí, valorizando la noción de 'salir adelante'; la pregunta de quién y por qué medios es poco frecuente” (Pearse, 2019).

Ian Bremmer, profesor de Geopolítica Aplicada en la Universidad de Columbia, sostiene que "el desafío que hoy enfrentamos es el desmantelamiento del orden mundial liderado por Estados Unidos, y la falta de un liderazgo mundial que intervenga y ocupe su lugar. Vivimos en un mundo G-Zero [...] y la recesión geopolítica es su efecto. En una recesión geopolítica, la fractura de la política global alimenta los riesgos globales en vez de ayudar a resolverlos" (Bremmer, 2020). La pandemia de COVID-19 envía otra señal de la disfuncionalidad de la política global impulsada por el neorrealismo. Es cierto que habrá un tecno-nacionalismo y proteccionismo estadounidense-euro-chino (Cronin, Doran y Rough, 2020). Bremmer capta cuatro factores que se deben abordar antes de que el mundo pueda resurgir del G-Zero:

a. La desigualdad y otras dislocaciones económicas derivadas de la globalización. El ascenso de la política de "mi país primero" en las democracias industriales avanzadas del mundo ha ido acompañado de la deslegitimación interna de las instituciones políticas democráticas, con repercusiones en la esfera internacional.

b. La tendencia de ciertas grandes potencias y potencias regionales emergentes a socavar los esfuerzos de las democracias más avanzadas y económicamente exitosas del siglo XX para hacer frente a sus muy reales crisis existenciales en el siglo XXI. Bremmer considera que Rusia es la primera entre las primeras, "que 30 años después del final de la Guerra Fría busca formas de desestabilizar a Occidente mientras impulsa su propia fortuna geopolítica".

c. La reducción de la eficiencia y la eficacia del sistema internacional. Las instituciones multilaterales que el mundo tiene actualmente para ayudar a administrar la política global y ayudar a la coordinación mundial ya no son adecuadas para ese propósito.

d. No es posible exagerar la indiferencia de Estados Unidos y la decisión de Trump de dar un paso atrás en el liderazgo global. Los 
estadounidenses sentían cada vez más que Estados Unidos asumía demasiado en nombre de otros, militarmente y de otras maneras (Bremmer, 2020).

Puesto que no aprendimos las lecciones de la crisis financiera de 2008, el coronavirus está aquí para inspirar con una reflexión profunda sobre la infraestructura económica y política existente, y el margen cada vez mayor entre el 1\% más rico y el $99 \%$ más pobre de la población. Desde 2008, muchos de nosotros, incluso yo mismo, hemos sufrido pérdidas de ahorros y una desigualdad vertiginosa. La clase media está perdiendo la batalla por mantener su nivel de vida ante el declive de su poder adquisitivo. Hoy estamos perdiendo mucho más: confianza en el Estado, en el ministerio de salud, en la economía y en todo el sistema para salvarnos de un virus diminuto. En países en desarrollo, las escuelas y universidades debieron pasar, sin estar preparadas, a la enseñanza a distancia, sin formación previa, conocimientos técnicos ni indicadores de éxito específicos.

En una entrevista realizada en su oficina en el MIT en 1991 durante la confusión científica sobre el SIDA, Thomas Kuhn le dijo a John Horgan "la pregunta sobre qué es el SIDA como condición clínica y qué es el agente de la enfermedad en sí mismo está sujeta a ajuste. Y así sucesivamente. Cuando se aprende a pensar de manera diferente sobre estas cosas, si se aprende, la cuestión del bien y del mal ya no parecerá ser la cuestión relevante" (Horgan, 2020). Con el coronavirus al acecho, sin una estrategia clara de contención o de cura, el mundo necesita volver a la mesa de diseño después de cuarenta años de globalización, libre comercio y otras construcciones ideológicas del neoliberalismo. También mencionaría la propuesta de David Harvey para reflexionar: “QQué pasa si cada modo de producción dominante, con su configuración política particular, crea un modo de oposición como imagen especular de sí mismo?" (Risager, 2016). Hay una oportunidad para que la izquierda, los humanistas, los intelectuales, los grupos de defensa de los ciudadanos y la sociedad civil global inicien un debate sobre la sociedad post-coronavirus, más allá del neorrealismo político y de la reorganización económica.

\section{REGRESO A LA DIMENSIÓN HUMANA Y LA DEMOCRACIA MORAL}

Algunos comentaristas defienden la socialdemocracia o el Estado social. La defensa de esos conceptos chocará con el escepticismo clásico 
sobre el colectivismo y otras formas de socialismo. Los conceptos de democracia "socialista" y "social" han sido contaminados y estigmatizados de un modo que provocarán reacciones similares en el futuro. E1 debate público puede evitarnos una batalla ya perdida en la década de 1950. La plataforma electoral de Bernie Sanders de 2016 incluía varias opciones de salud pública y matrícula universitaria gratuitas. Fue considerado un "socialista radical”, y el Partido Demócrata eligió a Hillary Clinton para enfrentar al candidato Trump. En marzo de 2020, Sanders relaciona el dilema del coronavirus con desafíos de salud pública anteriores en Estados Unidos. En su artículo de opinión "El coronavirus destaca las fallas de nuestro sistema económico y de atención médica”, señaló:

No es solo una cuestión de que en tiempos normales, trágica e increíblemente, el 13\% de los estadounidenses, unos 34 millones de personas, digan que un amigo o un familiar falleció recientemente por no poder pagar el tratamiento de una afección, según una encuesta de Gallup y West Health. Ahora, durante el brote de coronavirus, la falta de atención médica nos amenaza a todos, lo que demuestra que solo estamos tan seguros como la persona menos asegurada de Estados Unidos (Sanders, 2020).

Y pidió que en su país se hicieran pagos directos de emergencia de 2.000 dólares en efectivo cada mes a todas las personas mientras dure la crisis. "Es probable que ya estemos en recesión", afirmó Sanders.

Scott Gottlieb, ex comisionado de la Administración de Drogas y Alimentos de Estados Unidos (FDA) observó un patrón de "racionamiento" de las oportunidades de detección; mientras que los funcionarios del gobierno federal desalentaban a los hospitales para que desarrollaran y usaran sus propios kits de prueba porque debían obtener el permiso de la FDA para usarlos. Una encuesta reciente de Healthcare.com y YouGov realizada el 10 de marzo mostró que casi la mitad (el 48\%) de los participantes dijeron que no estaban muy seguros de poder hacer frente a los costos, porque superan los 3.000 dólares (el 23\%) o no estaban del todo seguros (el 25\%). Solo el 31\% dijo que podía pagar con sus ahorros; el $42 \%$ dijo que se endeudaría, con su tarjeta de crédito (22\%), su familia $(12 \%)$ o su banco (8\%).

Algunos economistas sienten nostalgia por las ideas de Adam Smith sobre el libre mercado, pues "anticipó gran parte de la corrupción y explotación que se observan actualmente en el sistema capitalista”. Smith advirtió contra algunos cambios explotadores del capitalismo porque ignoraban la virtud de la justicia. En La riqueza de las naciones escribió: "Perjudicar en algún grado los intereses de 
cualquier tipo de ciudadanos sin otro propósito que promover los de algún otro es evidentemente contrario a la justicia y la igualdad de trato”. El psicólogo industrial Paul Vorster señala:

Quizá no sea exagerado decir que Smith habría defendido la idea de que la ética empresarial consiste en hacer lo que es bueno para uno mismo (la organización) y para el otro (el consumidor y el empleado) de manera mutuamente benéfica. Atienda las necesidades de los consumidores y ellos harán lo mismo por usted (Vorster, 2019).

Vorster mantiene la esperanza de que las sociedades consideren una forma de capitalismo más pura como filosofía económica moral, y no solo como filosofía exclusivamente económica, para que las economías vuelvan a los principios de prosperidad, justicia y libertad (ibíd.).

Puesto que al parecer el coronavirus puso de rodillas al neoliberalismo con el cierre completo del sistema en todo el mundo, habrá un nuevo amanecer con preguntas más difíciles: ¿qué dirá el mundo postpandemia sobre la supervivencia de individuos, familias y sociedades? Será una oportunidad para revisar el paradigma del "contrato social", que históricamente ayudó al desarrollo del liberalismo clásico. Jeffery Sachs sostiene que el gobierno de Estados Unidos debe ser juzgado "por su incompetencia, su venalidad y su ignorancia, y eso aumentará nuestros costos y peligros de un modo sumamente deprimente y significativo" (Hasan, 2020).

Lo que hoy se necesita, más que nunca, es un debate público sobre la autonomía moral de los ciudadanos para redefinir los derechos y obligaciones del Estado y reconstruir su autoridad moral. El debate debe empezar sobre un tablero en blanco con un nuevo comienzo y un nuevo impulso. Defiendo una democracia moral y un estado moral como antítesis del neoliberalismo y del "capitalismo ético" mejor disfrazado, que se derivan de la lúcida explicación de Adam Smith de las fuerzas que configuran lo que aún llamamos "libre mercado": prosperidad, justicia y libertad. La realidad de la pandemia y la ausencia del Estado, sin una red de seguridad sanitaria proactiva, parecen justificar un retorno al derecho natural, a los principios kantianos y al paradigma de las necesidades humanas básicas. La nueva pandemia nos ha devuelto a una pregunta fundamental: ¿cómo conciliar la brecha cuando el Estado no protege al ciudadano?, ¿qué debe ser primero: las personas o las ganancias? Para usar la terminología de Immanuel Kant, ¿¿uál sería la "metafísica de las costumbres” de 2020, que constituye un "sistema de principios morales a priori que aplican el imperativo categórico a los seres humanos de todos los tiempos y culturas?" 
En su bien recibido libro En defensa del anarquismo, el académico y filósofo kantiano Robert Paul Wolff escribió:

La marca que define al Estado es la autoridad, el derecho a gobernar. La principal obligación de la persona es la autonomía, el rechazo a ser gobernado. Parece, entonces, que no puede haber solución al conflicto entre la autonomía del individuo y la autoridad putativa del Estado. En la medida en que la persona cumpla su obligación de ser autor de sus decisiones, resistirá la pretensión del Estado de tener autoridad sobre él" (Wolff, 1970).

La moralidad no se debe considerar una mera virtud utópica, sino más bien un impulso fáctico para el progreso colectivo. Desde el Tratado de Westfalia, el Estado, el sector privado, el mercado de valores y otras fuerzas estructurales han monopolizado el estatus de unidad de análisis. Deben ceder el lugar al individuo, la familia, el Estado de bienestar y el principio de salud para todos, educación para todos y prosperidad para todos. Kant argumentó que el principio moral supremo es un estándar de racionalidad que llamó "imperativo categórico”, al que caracterizó como un principio objetivo, racionalmente necesario e incondicional que siempre debemos seguir pese a cualquier deseo o inclinación natural hacia lo contrario. En la filosofía kantiana, toda ley-que representa el conjunto de normas que regula la relación entre el Estado y los ciudadanos- es percibe como un elemento que vincula directamente todos los campos: ética, filosofía del derecho, filosofía de la política y filosofía histórica. Kant mantiene el enfoque en el individuo, el sujeto y el yo moral libres, mientras que sitúa en la periferia la estructura y todas las instituciones políticas y regulaciones económicas, con una mente abierta a la paz perpetua. Instó al yo a "obrar solo de un modo en que podría querer que mi máxima se convierta en ley universal" (Kant, 2017).

En medio de la perturbación causada por el coronavirus, Edgar Morin, director emérito de investigación del Centre Nationale de la Recherche Scientifique (CNRS) en Francia, se mantiene optimista. Habló sobre el tema "No es demasiado tarde para cambiar el mundo" en la primera de una serie de conferencias públicas titulada Una época formidable. Observó que los humanos tienen muchos conocimientos, incluso sobre la muerte; que nunca han tenido tanta información y tanta experiencia. Pero que perdieron el sentido de dirección. Explicó: "Acumulamos mucha información sobre los humanos, pero aún no sabemos cómo ser humanos. En nuestras escuelas y universidades, el conocimiento de nuestra identidad humana no es parte del currículo académico. En términos de política, perdimos la 
brújula”. Y subrayó la pregunta” ¿A dónde debemos ir desde aquí?” (Merlet, 2020).

Desde hace décadas, algunos psicólogos sociales y teóricos de conflictos defienden la prudencia de un paradigma de necesidades básicas en el diseño de políticas públicas. Como dijo John Burton.

Si hay una adquisición material competitiva, por un lado, y un deseo individual de relaciones colaborativas, por el otro, la explicación de la preponderancia de las conductas adversarias y agresivas tendría que ser las condiciones impuestas por los sistemas a medida que evolucionan. Si es así, los conflictos en todos los niveles sociales se deben a fallas anteriores para incluir un elemento humano en las instituciones y en la toma de decisiones, y para emplear los recursos intelectuales disponibles con el fin de revaluar continuamente las instituciones y normas sociales y así resolver los problemas a medida que surgen (Burton, 1998).

E1 fundador de Estudios de la Paz y candidato al Premio Nobel de la Paz en 2016, Johan Galtung, aboga por la fuerte interconexión entre necesidades humanas básicas y desarrollo. Dice que "tiene sentido hablar de ciertos tipos de necesidades - de seguridad, de bienestar, de identidad y de libertad-para adoptar la clasificación que usamos aquí, y postulamos que de una forma u otra los seres humanos en todas partes y en todo momento han intentado e intentarán hacerles frente de maneras muy diferentes"(Galtunf, 1979).

\section{REFERENCIAS BIBLIOGRÁFICAS}

Aizenman, N. (2020). New research: Bats harbor hundreds of coronaviruses, and spillovers aren't rare. NPR, [https://www.npr.ora/sections/ aoatsandsoda/2020/02/20/807742861/new-research-bats-harborhundreds-of-coronaviruses-and-spillovers-arent-rare].

Amadeo, K. (2020). Why trickle-down economics works in theory but not in fact. The Balance, [https://www.thebalance.com/trickle-downeconomics-theorv-effect-does-it-work-3305572].

Beauchamp, Z. (2020). The deep ideological roots of Trump's botched coronavirus response. VOX, [https://www.vox.com/policv-and-politics/2020/3/17/21176737/coronavirus-COVID-19-trump-responseexpertise].

Braw, E. (2020). The EU is abandoning Italy in its hour of need. Foreign Policy, [https://foreignpolicy.com/2020/03/14/coronavirus-euabandoning-italy-china-aid/].

Bremmer, I. (2020). We are in a geopolitical recession. That's a bad time for the global coronavirus crisis. Time, [https://time.com/5802033/ geopolitical-recession-global-crisis/].

Burton, J. (1998). Conflict resolution: The human dimension. International Journal of Peace Studies, 3(1), 1-27.

Campbell, K. M. y Doshi, R. (2020). The coronavirus could reshape global order. Foreign Affairs, [www.foreignaffairs.com/articles/ 
china/2020-03-18/coronavirus-could-reshape-global-order?utm campaign $=$ The $\% 20$ Coronavirus $\% 20$ Could $\% 20$ Reshape $\% 20$ Global $\% 20$ Qr\%20der\&utm_medium=newsletters\&utm_source=twofa].

CDC. (2020). Situation summary, [https://www.cdc.gov/coronavirus/2019ncov/cases-updates/summary.html].

Cohen, E. (2020). Infected people without symptoms might be driving the spread of coronavirus more than we realized. CNN, [https:// edition.cnn.com/2020/03/14/health/coronavirus-asvmptomatic-spread/ index.html].

Cronin, P. M. Doran, M. et al. (2020). Political implications of the coronavirus, [www.hudson.org/research/15816-geopolitical-implicationsof-the-coronavirus].

Daalder, I. (2020). Commentary: China's secrecy has made the coronavirus crisis much worse. Chicago Tribune, [www.chicagotribune.com/ opinion/commentary/ct-opinion-china-coronavirus-epidemic-secrecydaalder-20200213-xs5uhj21qverbde6aprxldh5q4-story.html].

Detrixhe, J. (2020). Nobel Prize winning economist Robert Shiller says this economic disruption is different, [https://qz.com/1818061/ robert-shiller-says-the-coronavirus-disruption-is-different-fromother-economic-crises/].

Friedman, M. (1951). Neoliberalism and its prospects, Farmand, 89-93.

Gaffney, A. (2020). America's extreme neoliberal healthcare system is putting the country at risk. The Guardian, [https://www.theguardian.com/commentisfree $/ 2020 / \mathrm{mar} / 21 /$ medicare-for-all-coronavirusCOVID-19-single-paver].

Galtung, J. (1979). The new international economic order and the basic needs approach. Alternatives, 4(4), 455-476.

Hasan, A. (2020). Capitalism versus coronavirus. The Intercept, [https:// theintercept.com/2020/03/12/capitalism-vs-the-coronavirus/].

Heffer, G. (2020). Coronavirus: PM moves UK to 'suppression' after new analysis of COVID-19 death rate. Sky, [https://news.skv.com/ story/coronavirus-govt-ramped-up-measures-after- new-predictionof-250-000-deaths-11958680].

Horgan, J. (2020). The coronavirus and right-wing Postmodernism. Scientific American, [https://blogs.scientificamerican.com/cross-check/ the-coronavirus-and-right-wing-postmodernism/].

Hutton, W. (2020). Coronavirus won't end globalisation, but change it hugely for the better. The Guardian, www.theguardian.com/commentisfree/2020/mar/08/the-coronavirus-outbreak- shows-us-that-no-onecan-take-on-this-enemy-alone].

Ives, B. (2020). Dean Koontz: Did he predict the coronavirus in The eyes of darkness in 1981? [https://wmmr.com/2020/03/14/dean-koontz-didhe-predict-the-coronavirus-in-eves- of-darkness-1981/].

Laurent, L. (2020). Salvini and Le Pen don't have a coronavirus cure. Bloomberg, [https://www.bloomberg.com/opinion/articles/2020-02-25/ salvini-and-le-pen-don-t-have-a-european-coronavirus-cure].

LePan, N. A (2020). Visual history of pandemics. Word Economic Forum, [https://www.weforum.org/agenda/2020/03/a- visual-history-ofpandemics] 
Lewis, A. (2020). Coronavirus crash is a true 'black swan' as Goldman thought the economy was nearly recession-proof'. $C N B C$, [https:// www.cnbc.com/2020/03/14/goldman-thought-economy-was-recessionproof-in-january---it-wasnt.html].

Merlet, P. (2020). Video: Pas trop tard pour changer le monde, selon Edgar Morin. La Tribune, [https://toulouse.latribune.fr/evenements/2020-03-17/video-pas-trop-tard-pour-changer-le-monde-selon-edgar-morin-842465.html].

Micallef, J. V. (2020). The geopolitics of the coronavirus. Military. com, [https://www.military.com/dailv-news/2020/02/25/geopoliticscoronavirus.html].

Mirowski, P. y Plehwe, D. (2009). The road from Mont Pelerin: the making of the neoliberal thought collective. Cambridge, Mass.: Harvard University Press.

Mosher, S. W. (2020). Don't buy China's story: The coronavirus may have leaked from a lab. The New York Post, [https://nypost.com/2020/02/22/ dont-buy-chinas-story-the-coronavirus-may-have-leaked-from-a-lab/].

Moustakbal, J. (2017). Despotism, neoliberalism and climate change: Morocco's catastrophic convergence. Middle East Eye, [https://www. middleeasteve.net/big-story/despotism-neoliberalism-and-climatechange-moroccos-catastrophic-convergence].

New Frame. (2020). Coronavirus and the crisis of capitalism. New Frame [https://www.newframe.com/coronavirus-and-the-crisis-ofcapitalism/].

Pearse, W. (2019). A critique of Neoliberalism. INOMICS, [https:// inomics.com/insight/a-critique-of-neoliberalism-1379580].

Peters, C. (1982). A Neo-Liberal's manifestó. The Washington Postk, [https://www.washingtonpost.com/archive/opinions/1982/09/05/aneo-liberals-manifesto/21cf41ca-e60e-404e-9a66-124592c9f70d/].

Pettersson, K. (2020). The corona crisis will define our era. Social Europe, [https://www.socialeurope.eu/the-corona-crisis-will-define-our-era].

Rachman, G. (2020). How Beijing reframed the coronavirus response narrative. Financial Times, [https://www.ff.com/content/20ab52d8676a-11ea-800d-da70cff6e4d3].

Reich, R. (2020). Coronavirus won't respond to trickle-down economics. Salon, [https://www.salon.com/2020/03/11/robert-reich-coronaviruswont-respond-to-trickle-down-economics partner/]

Risager, B. S. (2016). Neoliberalism is a political project: An interview with David Harvey. Jacobin, [https://www.jacobinmag.com/2016/07/ david-harvey-neoliberalism-capitalism-labor-crisis-resistance/].

Roberts, L. y Green, A. (2019). The state of the Trump economy. CAP, [https://www.americanprogress.org/issues/economy/ news/2019/02/05/465835/state-trump-economy/].

Roberts, A. y Lamp, N. (2020). Is the virus killing globalization? There's no one answer. Barron's, [https://www.barrons.com/articles/is-thevirus-killing-globalization-theres- no-one-answer-51584209741].

Rodrik, R. (2017). The fatal flaw of neoliberalism: it's bad economics. The Guardian, [https://www.theguardian.com/news/2017/nov/14/thefatal-flaw-of-neoliberalism-its-bad-economics]. 
Sachs, J. (2020). The Trump administration's ludicrous approach to coronavirus vaccine. CNN, [https://edition.cnn.com/2020/03/05/opinions/ ludicrous-plan-coronavirus-vaccine-opinion-sachs/index.html.

Sanders, B. (2020). Coronavirus highlights the flaws in our health care and economic systems. CNN, [https://edition.cnn.com/2020/03/15/ opinions/bernie-sanders-opinion-coronavirus-health-care-economicsvstem-flaws/index.html].

Scott T., A. y Miller L., S. (2020). Containing coronavirus: Where democracy struggles - and thrives. Christian Science Monitor, [https://www. csmonitor.com/World/2020/0302/Containing-coronavirus-Wheredemocracy-struggles-and-thrives].

Spinney, L. (2020). Coronavirus and the geopolitics of disease. The Statesman, [https://www.newstatesman.com/politics/health/2020/02/ coronavirus-and-geopolitics-disease].

Tharoor, I. (2020). How epidemics have changed the world. The Washington Post, [https://www.washingtonpost.com/world/2020/03/06/ how-epidemics-have-changed-world/]

The Guardian. (2020). Coronavirus: Anger in Germany at report Trump seeking exclusive vaccine deal, [https://www.theguardian.com/ world/2020/mar/16/not-for-sale-anger-in-germany-at- report-trumpseeking-exclusive-coronavirus-vaccine-deal].

Timsit, A. (2020). China is mobilizing to control the narrative on coronavirus. Quartz, [https://qz.com/1812162/china-mobilizes-againstmedias-malicious-coronavirus-coverage/].

Turzi, M. (2020). Coronavirus: The weight of geopolitics and macroeconomics. Worldcrunch, [https://www.worldcrunch.com/world-affairs/ coronavirus-the-weight-of-geopolitics-and-macroeconomics].

Urie, R. (2020) The Neoliberal plague. Counterpunch, [https://www. counterpunch.org/2020/03/06/the-neoliberal-plague/].

Vorster, P. (2019). The three principles of ethical capitalism. Ethics Institute, [https://www.tei.org.za/index.php/resources/articles/ethicsopinions/7712-the-three-principles-of-ethical-capitalism].

Ward, A. (2020). The Saudi Arabia-Russia oil war, explained. Vox, [https:// www.vox.com/2020/3/9/21171406/coronavirus- saudi-arabia-russiaoil-war-explained]

West, C. (2016). Goodbye, American Neoliberalism. A new era is here. The Guardian, [https://www.theguardian.com/commentisfree/2016/ nov/17/american-neoliberalism-cornel-west-2016-election].

White, B. (2020). How ugly could it get? Trump faces echoes of 1929 in coronavirus crisis. Politico, [https://www.politico.com/news/2020/03/16/ trump-faces-1929-save-economy-133053].

WHO. (2020). ICC-WHO joint statement: An unprecedented private sector call to action to tackle COVID-19, [https://www.who.int/newsroom/detail/16-03-2020-icc-who-ioint-statement-an-unprecedentedprivate-sector-call-to-action-to-tackle- COVID-19].

WHO. (2020). Novel coronavirus (COVID-19) Situation, [https://experience.arcgis.com/experience/685d0ace521648f8a5beeeee1b9125cd].

Wolff, R. P. (1970). In defense of anarchism. Nueva York: Harper \& Row. 
World Economic Forum. (2020). Coronavirus is officially a pandemic but we can change its course: Today's WHO briefing, [https://www. weforum.org/agenda/2020/03/coronavirus-is-official-a-pandemic-butwe-can-change-its-course-who-briefing/].

Wright, T. y Campbell, K. M. (2020). The coronavirus is exposing the limits of populism. Atlantic, [https://www.theatlantic.com/ideas/archive/2020/03/geopolitics-coronavirus/607414/].

Yamada, S. (2020). Neoliberalism and the coronavirus. Counterpunch, [https://www.counterpunch.org/2020/02/07/neoliberalism-and-thecoronavirus/]

Zeihan, P. (2020). The "gift" of coronavirus. Zeihan on Geopolitics, [https:// zeihan.com/the-gift-of-coronavirus/]. 